\title{
Reminding State Owned Enterprises (BUMN) Management Using the Principle of 'Business Judgment Rule': A Preliminary Note
}

\author{
Teuku Syahrul Ansari \\ Ph.D Student in Universitas Dipenegoro (Undip), Semarang, Indonesia \\ alonansari@gmail.com
}

\begin{abstract}
This paper explains that the development of BUMN (state owned enterprises) as a corporation that carries out social and business missions is facing constitutional juridical problems and facing the challenges of globalization. Factually, at this time legal development cannot be separated from the influence of globalization. Globalization in the economic field has affected various fields of the business sector in the world. This globalization is followed by the globalization of law, which causes substantially various laws and agreements to spread across national borders, which causes the merging of legal principles (especially in the economic sector) from one country to another. For Indonesia, the logical consequence of this development is the demand to harmonize the principles of economic law in Indonesia, with the principles of economic law in the international world. Without harmonization, Indonesia can be ostracized in international business activities, because there is no certainty for legal protection for business and investment activities that are commonly carried out globally. The Constitutional Court in case number 48 / PUU-XI / 2013 and case No. 62 / PUU-X1 / 2013 dated May 22, 2013 decided that management BUMN must use the principle of Business Jugment Rule. In the ruling, it was also stated that state owned finances were state finances. As a result, this ruling brings legal certainty about the position of finance of BUMN.
\end{abstract}

Keywords : state owned enterprises; globalization; economic law; principle; Business Jugment Rule; corporation; Indonesia.

\section{Introduction}

The Constitutional Court in case number 48 / PUU-XI / 2013 and case No. 62 / PUU-X1 / 2013 dated May 22, 2013 which was read on September 18, 2014, has decided that the management BUMN uses the principle of the Business Judgment Rule. In the ruling, it was also stated that BUMN finance were state finances. As a result, this ruling brings legal certainty about the position of finance of BUMN.

Principles of Business Judgment Rules are one of the important elements in Law No. 40 of 2007 concerning Limited Liability Companies, so that they have standards regarding accountability to be able to see which business decisions are taken in accordance with procedures in the interests of the company or whether business decisions are taken for the director's personal interests. ${ }^{1}$

\section{Review of Literatures}

The terminology of Business Judgment Rule in the theory of its library is the legal doctrine of companies originating from America that adhere to the common law legal system. Business Judgment Rules are one of several doctrines in corporate law that must be run by directors to fulfill fiduciary duty. According to Angela Scheeman, Business Judgment Rule is a doctrine that teaches that company directors can be released from responsibility for losses

\footnotetext{
${ }^{1}$ Prasetio, Dilema BUMN Benturan Penerapan Business Judgment Rule (BJR), PT Rayyana Komunikasindo, Jakarta, 2014, PP. 143-144.
} 
incurring from a business decision-making action, in which the decision-making actions have gone through a process, careful and in good faith. ${ }^{2}$

The concept of the Business Judgment Rule itself has actually been implemented in one of the states in United States, which adheres to the common law legal system around 173 years ago. United States that applies the Business Judgment Rule system is Delaware. Indonesia in its development as a citizen of the world cannot be separated from the influence of globalization, including the legal system in force in United States. According to the applicable corporate law in Delaware, Business Judgment Rule is a derivative of the basic principle that a company is managed by its directors. The directors in running the company are required not to despair in fulfilling fiduciary duty in the interests of the company and shareholders.

Some notions of Business Judgment Rule can be seen, as defined by the Black Law Dictionary saying:

Business Judgment Rule is the presumption that in making business decisions not involving direct self-interest or self-dealing, corporate directors act on an informed basis, in good faith, and the honest belief that their actions are in the corporation best interest. ${ }^{3}$

Whereas in Indonesia, Sutan Remy Sjahdeini said:

Business Judgment Rule is a business consideration of members of the board of directors who cannot be challenged or contested or rejected by the court or shareholders. The members of the board of directors cannot be burdened with responsibility for the consequences that arise, because a business consideration has been taken by a member, the board of directors concerned even if the business consideration is wrong, except in certain cases. ${ }^{4}$

It can also be seen that Hendra Setiawan Boen provides a definition:

The Business Judgment Rule arises as a result of the implementation of fiduciary duty by a board of directors, that is the principle of duty of skill and care, so that all errors that arise after the principle of duty and skill are implemented it get the consequence that the directors get personal liability if there is an error in their decision. ${ }^{5}$

From several definitions above, it can be said that Business Judgment Rule basically adheres to the principle that a company's directors cannot be held accountable for losses arising from a decision-making action, as long as the directors in making these decisions have been based on good intentions and are entirely in the interest company. Indeed, the Business Judgment Rule in Indonesian corporate law is not explicitly stated, but if we want to examine it, in Law Number 40 of 2007 concerning Limited Liability Companies, there are several articles that clearly require the Business Judgment Rule in managing the company. Article 69 paragraph 4, Article 92 paragraph 1, Article 97 paragraph 5 and Article 104 paragraph 4 in the Limited Liability Company Law.

\section{Discussion}

Article 69 paragraph 4 reveals that Members of the Board of Directors and Members of the Board of Commissioners are exempt from the responsibilities referred to in paragraph 3 if

\footnotetext{
${ }^{2}$ Prasetio, Dilema BUMN Benturan Penerapan Business Judgment Rule... pp. 143-144.

${ }^{3}$ Byan A Camer, Black's Law Dictionary, Thomson West, Massachusetts, P. 200.

${ }^{4}$ Sutan Remy Sjahdeini, Tanggungjawab Pribadi Direksi dan Komisaris, Journal of Business Law Volume 14, July 2001.

${ }^{5}$ Hendra Setiawan Boen, Bianglala Business Judgment Rule, PT Tata Nusa, Jakarta, 2008, P. 100
} 
it is proven that the situation is not due to his mistake. Whereas Article 97 paragraph 5 of the Limited Liability Company Law states that members of the Board of Directors cannot be held responsible for losses as referred to in paragraph 3 if they can prove:

a. The loss is not due to error or negligence;

b. Has done management in good faith and caution;

c. For interests and in accordance with the purpose and objectives of the Company;

d. Do not have a conflict of interest, either directly or indirectly, over management actions that result in losses; and

e. Has taken action to prevent the occurrence or continuation of these losses.

This article expressly states that the directors are responsible for all actions and decisions made, but the directors can avoid the demands of personal accountability, if the directors can prove the basis and reasons referred to in Article 97 paragraph 5 of the Limited Liability Company Law. Explanation of Article 97 paragraph (5) letter d states that what is meant by "taking actions to prevent arising or continuing losses" includes steps to obtain information regarding management actions that can cause losses, including through the Board of Directors meeting forum.

Then, Article 104 paragraph 4 of the Limited Liability Company Law states that directors are not responsible for the bankruptcy of the Company as referred to in paragraph 2 if it can prove:

a. Bankruptcy is not due to an error or negligence;

b. Has done management in good faith, prudence, and full responsibility for the interests of the company and in accordance with the goals and objectives of the company;

c. Does not have a conflict of interest, either directly or indirectly, for the management actions taken; and

d. Has taken action to prevent bankruptcy.

Furthermore, the provision of Article 104 paragraph (4) of the Limited Liability Company Law states that as long as the board of directors can prove matters as stated in the provisions of Article 104 paragraph (4) of the Limited Liability Company Law, the member of the board of directors cannot be held accountable for the bankruptcy experienced by the Company That limited.

In the meantime, Article 11 of Law Number 19 of 2003 concerning state owned enterprises (BUMN) regulates that the management of Persero is carried out based on the Law on Limited Liability Companies, which currently applies is Law Number 40 of 2007 concerning Limited Liability Companies. The ratio legis is if there is a loss experienced by the company or better known as corporate loss caused by the application of the Business Judgment Rule, then the loss does not constitute a State loss, but is considered a company loss as a consequence of business as usual.

The theory with the Constitutional Court Decision number 25 / PUU-XIV / 2016 related to Articles 2 and 3 of the Corruption Act (Tipikor) decided that the word "can" contained in Articles 2 and 3 of the Corruption Law was abolished. Thus, the crime of corruption according to the article must meet the loss of the state or the real country's economy. As for the content of Article 2 paragraph (1) Corruption Law,

"Anyone who violates, and commits an act enriches himself or another person or a corporation that can harm the country's finances or the country's economy, will be convicted to prison with life imprisonment or imprisonment for a minimum of 4 (four) years and a 
maximum of 20 (twenty) year and a fine of at least Rp. 200,000,000.00 (two hundred million rupiahs) and at most Rp. 1,000,000,000.00 (one billion rupiah)".

Then, Article 3 of the Corruption Law states:

"Everyone who aims to benefit himself or another person or a corporation, misusing the authority, opportunity or means available to him because of a position that can harm the state's finance or the country's economy, will be convicted to prison with life imprisonment or imprisonment for a minimum of 1 (one) year and a maximum of 20 (twenty) year and a fine of at least Rp. 50,000,000.00 (fifty million rupiahs).

As for the consideration, there is a fundamental reason for the Constitutional Court to change the assessment of constitutionality in the previous decision, because previous assessments have been evident over and over again causing legal uncertainty and injustice in eradicating corruption. Thus the word "can" in Article 2 paragraph (1) and Article 3 of the Corruption Law is contrary to the 1945 Constitution.

In comparison to the State's loss, the case that is currently under investigation is bailout assistance to insurance giant AIG (American International Group Inc). The Federal Reserve said in a statement that it would provide GAO with all records and personnel needed to conduct the inspection. GAO is a unit of audit, evaluation and investigation of Congress. The AIG itself, through its controversial acknowledgment, has used more than USD 90 billion in federal assistance to fund foreign and local banks. Some of the banks that receive funding from AIG have already received billions of dollars in bailouts from the US government - which are taxpayers' money through AIG. According to AIG, the funds for the banks aim to cover their losses on complex mortgage investments, as well as the need for guarantees for other transactions. AIG received over US $\$ 170$ billion in bailouts from the US government, and funds for banks were taken from the bailout. The leading company led by Edward Liddy is worried that if AIG goes bankrupt, it will destroy banks and consumers in various countries. The company, which is about eighty percent of its shares now controlled by taxpayers in the US, has announced a list of recipients of funds from AIG. Some of the biggest recipients were Goldman Sachs (USD 12.9 billion), three European banks, Societe Generale, France (USD 11.9 billion), Deutsche Bank, Germany (USD 11.8 billion), Barclays PLC, United Kingdom (USD 8, 5 billion), and Merrill Lynch for USD 6.8 billion. Other banks received between USD 1 billion and USD 3 billion from AIG securities loan units, including Citigroup Inc., Swiss UBS AG, and Morgan Stanley. ${ }^{6}$

Based on Article 114 paragraph (5) Law No. 40 of 2007 concerning Limited Liability Companies states that members of the Board of Commissioners cannot be held responsible for losses as referred to in paragraph (3) if they can prove:

a. has carried out supervision in good faith and prudence for the interests of the Company and in accordance with the purposes and objectives of the Company;

b. do not have personal interests, directly or indirectly, for the management of the Board of Directors which results in losses; and

c. Has provided advice to the Board of Directors to prevent such losses from arising or continuing.

\footnotetext{
${ }^{6}$ Data Observation, condected by Sindonews.com, from https://ekbis.sindonews.com/read/1308869/35/28-bankterbesar-dunia-beraset-lebih-usd1-triliun-11-dari-asia-1527226276
} 
The provisions above are the basis for implementing the Business Judgment Rule. In comparison, in the corporate law in United States, American states regulating this Business Judgment Rule vary slightly. For example, State of Delaware has no nearly two-century single formulation of this Business Judgment Rule. However, since 1984 the Delaware formulation is probably very famous. The Delaware standard has shifted in recent years, where since 1984 the Supreme Court of Delaware has consistently established the characteristics of the Business Judgment Rule as: ${ }^{7}$

A presumption that in making a business the decision of the directors of a corporation acted on an informal basis, in good faith and in the honesty of the best interests of the company. The decision to establish facts rebutting the presumption.

As a practical matter, the presumption held by the Business Judgment Rule is impossible to master, at least in cases where the director does not have a conflict of interest. In that context the shareholders as plaintiffs are required to show whether the signing of the substance of the business decision means that "no content businessperson will make that decision" or the board of directors has made a major omission in informing himself of all material information that makes sense available before he acts.

Directors have "duty of care" and "duty of loyalty", "obligation to be careful" and "obligation to be loyal" to companies and shareholders. Differences exist between the two that are run by the directors of the company and its shareholders. To determine whether a director violates the obligation to be careful, the court uses the Business Judgment Rule and fair standards. The court analyzes the two obligations differently, depending on whether the transaction is a challenge involving an unauthorized, or interested director, a self-dealing director. If the director is not interested, a Business Judgment Rules are applied to determine whether the director in question violates his duty to be careful (duty of care); but if the director is interested, the presumption of the business judgment rule is the fairness applied to determine the director violates his duty to loyalty (duty of loyalty). Directors always have this obligation to the company and its shareholders.

The application of the Business Judgment Rules is a development in corporate law. In the development of a country now, with rapid economic and technological developments, according to Sri Redjeki Hartono, ${ }^{8}$ making economic activities is sometimes difficult to balance with legal development. These difficulties require state intervention to regulate and provide protection to all parties, both consumers and producers (business actors), which often triggers conflict, both among consumers and actors, and among fellow economic actors. In fact, law should provide a system that makes economic actors do their roles well.

Economic actors, basically have very important functions. Because it has two functions at once, namely as a supplier of all the needs of the community, both primary, secondary and tertiary. At the same time, they also function as absorbers of community labor, which can economically increase purchasing power. These economic actors can be individuals, business entities not legal entities (Firms or CVs), business entities that are legal entities such as cooperatives and limited liability companies, and economic actors in legal entities with sophisticated qualifications. The Persero PT has technical / non-technical requirements including sufficient financial capability requirements and is supported by professional human

\footnotetext{
${ }^{7}$ Peter V. Letsou, "Implications of Shareholder Diversification On Corporate Law And Organization: The Case of The Business Judgment Rule", 77 Chicago-Kent Law Review (2001), p. 181.

${ }^{8}$ Sri Redjeki Hartono, Hukum Ekonomi Indonesia, Bayu Media Publishing, Malang, 2007, P. V.
} 
resources in accordance with their fields. These economic actors are usually on par with global economic actors. ${ }^{9}$

According to Law Number 19 Year 2003 concerning State-Owned Enterprises (BUMN Law) is a business entity who is entire or part of its capital is owned by the state through direct participation derived from separated state assets. Whereas the company, hereinafter referred to as Persero, is a state-owned company in the form of a limited liability company whose capital is divided into shares whose total or at least $51 \%$ (fifty one percent) shares are owned by the Republic of Indonesia whose main purpose is to pursue profits.

Historically the presence of SOEs in Indonesia existed before Indonesian independence, as explained by Aminuddin, ${ }^{10}$ that in the days of the Dutch East Indies government businesses were known, such as spoorswagen (SS), Gemeenschapelijke Mijnbow Maatscapij Biliton (GMB), the tin mining company on Belitung Island, Pegadaian Company, PLN and so on. Then, after the independence of Dutch companies, because they had strategic values nationalized to become Indonesian state companies. ${ }^{11}$ In the independence era, BUMNs were also established based on the provisions in Article 33 paragraph (2) of the 1945 Constitution.

Then in its historical development, the basic philosophical interpretation of the existence of SOEs rested on the provisions of the 1945 Constitution, Article 33 specifically paragraphs (2) and (3) which contained the intention that; production branches that are important to the State and which control the livelihood of many people are controlled by the State. Then the earth, water, and natural resources contained therein are controlled by the State and are used for the greatest prosperity of the people. Thus the first task of the State to form a business entity is to fulfill all the needs of the community, when these sectors cannot yet be carried out by the private sector. Then such tasks are translated as a form of "pioneering" effort by the State that makes BUMNs become agents of development.

BUMN must be independent that is using the instruments it has to achieve the goals set by the political system without any interference from parties outside the BUMN. This is called "instrument independence" not "goal independence". The independent consequence for SOEs is to be more accountable for actions taken in transparent regulation and supervision. ${ }^{12}$

The understanding of BUMN as an agent of development continued up to the period of the 80s, which later had a negative impact, because the control function of SOEs was considered to be very weak, BUMNs were a hotbed of corruption and so on. In the period of the late 80s, the management of BUMN was addressed to focus its business. This is actually a reflection of the implementation of Good Corporate Governance (GCG) programs, among others by publishing financial reports, meaning that there has been learning and discipline of SOEs towards the implementation of GCG principles (openness) as well as the learning of

\footnotetext{
9 Ibid. pp. 95 -99.

${ }^{10}$ Aminuddin Ilmar, Hak Menguasai Negara Dalam Privatisasi BUMN, kencana Prenada Media Grup, Jakarta, 2012, P. 73.

${ }^{11}$ Prasetio, Dilemma BUMN Benturan Penerapan Business Judgement Rule (BJR) Dalam Keputusan Bisnis Direksi BUMN, Rayyana Komunikasindo, Jakarta, 2014, P. 79.

12 Bismar Nasution, "Pengaturan Dan Pengawasan Lembaga Jasa Keuangan Menurut Undang-Undang Nomor 21 Tahun 2011 Tentang Otoritas Jasa Keuangan", Paper, Presented at the Socialization of Law Number 21 Year 2011 concerning the Financial Services Authority, Integrated Financial Services Industry Supervision, carried out by the Capital Market and Financial Institution Supervisory Agency in collaboration with the University of Medan Area, Santika Medan Hotel, 19 June 2012, P. 2.
} 
capital market protocols starting from that time. By applying the principles of GCG, as well as the intention to be able to separate ownership functions and functions as regulators. If this is not understood, the separation of functions will result in interventions starting from the owner and will be followed by other parties with interests.

In the reform era, there were BUMN Directors in the form of Persero subject to corruption. Because doing transactions that are considered detrimental to the country's finances. This is due to unclear formulation of state finances. But the losses suffered because one transaction can still be accused of corruption. Basically, BUMN is a Limited Liability Company, thus subject to Law No. 40 of 2007 concerning Limited Liability Companies (PT Law). The supervision mechanism and implementation of company management are subject to the PT Law and its Articles of Association. Violations of the PT Law and its Articles of Association result in perpetrators who have limited responsibility being personal responsibility. ${ }^{13}$

The violation is not a criminal offense, except if it is proven that the perpetrator accepts bribes or commits embezzlement into the realm of criminal law, because BUMN Persero is a legal entity that has wealth (vermogen) separate from the owner's wealth. The rights and obligations of legal entities are completely separate from the rights and obligations of their owners and managers. In addition, legal entities (rechts persoon) are legal subjects, namely those who have rights and obligations such as humans (natuurlijk persoon). Like humans, legal entities can sue and be sued and have their own assets. ${ }^{14}$

Based on the Persero's philosophy, the BUMN Directors in the form of a company should not be subject to corruption. In addition, it is confirmed legally in Article 2 letter g of Law No. 17 of 2003 concerning state finance, that state finances, among others, state wealth / regional wealth managed by themselves or by other parties in the form of money, securities, accounts receivable, goods, and other rights that can be valued with money, including assets separated on state / regional companies. Furthermore, Article 4 paragraph (1) of the BUMN Law states that "BUMN is and originates from separated state assets" In the explanation of Article 4 paragraph (1) it is said that

"What is meant by segregation is the separation of state assets from the State Revenue and Expenditure Budget to be used as state capital participation in SOEs, and guidance and management are no longer based on the State Budget and Expenditure system, but guidance and management are based on content corporate principles. ";

The aforementioned articles, which constitute a special law on SOEs, are clearly stated that BUMN capital comes from state assets that have been separated from the State Budget and furthermore the guidance and management are not based on the APBN system but are based on content corporate principles. ${ }^{15}$

Provisions that also underlie that BUMN Persero as a legal entity that cannot be subject to corruption is Article 1 point 6 of Act No. 1 of 2004 concerning State Treasury:

\footnotetext{
${ }^{13}$ Arifin P Soeriatmaja, "Badan Pemeriksa Keuangan Selaku Auditor dari Perspektif BUMN," Business Law Journal, Volume No.26 No.1 of 2007, P. 26.

${ }^{14}$ Ridwan Khairandy "Konsepsi Kekayaan Negara yang Dipisahkan Dalam Perusahaan Negara" Business Law Journal, Volume No.26 No.1 of 2007, P 32.

${ }^{15}$ Tjip Ismail, "Peranan BUMN dalam Perspektif Pendapatan Negara: Tinjauan Dari Perspektif Pajak" Business Law Journal, Volume No.26 No.1 of 2007, P. 40.
} 
"State Receivables are the amount of money that must be paid to the Central Government and / or the rights of the Central Government which can be valued with money as a result of the agreement or other consequences based on applicable laws or other legal consequences."

Furthermore, based on the provisions of Article 8 of Law No. 49 Prp. In 1960 the State Debt Affairs Committee stated that "State receivables or debt to the State is the amount of money that must be paid to the State or Bodies which are either directly or indirectly controlled by the State based on a regulation, agreement or any cause". In his explanation it is said that the State receivables also include accounts receivable "bodies which are generally part or all of their assets and capital, for example State Banks, State Universities, State Companies, Supplies and Supplies Foundations, Foodstuffs Foundation and so".

The BUMN Directors are prosecuted for corruption, because law enforcement officers based on Law Number 31 of 1999 concerning Eradication of Corruption Crime as amended by Act No. 20 of 2001, among others, state that state finances are all state assets in any form, which is separated or not separated, including all parts of the state's wealth and all rights and obligations that arise due to: being in the control, management and accountability of officials of state institutions, both at the central and regional levels; and is in the control, management and responsibility of state owned enterprises / Regional-Owned Enterprises, foundations, legal entities, and companies that include state capital, or companies that include third party capital based on agreements with the State. Furthermore, Law Number 15 of 2006 concerning the Supreme Audit Agency regulates, among other things, that the BPK is tasked with examining the management and responsibility of state finances carried out by the Central Government, Regional Governments, other State Institutions, state owned enterprises, Public Service Bodies, Business Entities Regional Ownership, and other institutions or agencies that manage state finances. Accordingly, what is meant by state finance includes all elements of state finance as referred to in the law governing state finances. ${ }^{16}$

Legal uncertainty towards legal proceedings is also caused by different interpretations of state finances. On the one hand, state finance is interpreted separately, on the other hand there are those that equate it with the state budget. ${ }^{17}$ According to Otto Ekstein, arguing that the budget is a complete breakdown of expenditures and revenues estimated by the government. ${ }^{18}$ Furthermore, Van der Kemp argues that state finance is all rights that can be valued with money, as well as everything (whether in the form of money or goods) that can be used as state property in relation to these rights. On the other hand, Arifin P. Soeria Atmadja examines etymological budgetary words, which are derived from the words "fencing" or "roughly" or "calculation", so that the state budget means an estimate or calculation of the amount of expenditure or expenditure to be spent by the state. ${ }^{19}$

Arifin P. Soeria Atmadja stated that according to C. Goedhart in the Netherlands the budget is called begrooting which is derived from the Old Dutch grotent which means imitation. This term was later taken over by the Dutch Constitution in 1814. Unlike in England, the budget is called a budget that comes from French bouge or bougette which means "bag" on

\footnotetext{
${ }^{16}$ See Article 8 and its explanation of Law No. 49 Prp of 1960 about the State Receivables Affairs Committee.

${ }^{17}$ See W. Riawan Tjandra, Hukum Keuangan Negara, Publisher: PT Gramedia Widiasarana Indonesia, Jakarta, 2006, pp. 1-3.

${ }^{18}$ Otto Eckstein, Keuangan Negara, Translation from "Public Finance", Jakarta: PT Bina Aksara, 1981, P. 45.

${ }^{19}$ Arifin P. Soeria Atmadja, Mekanisme Pertanggungjawaban Keuangan Negara: Suatu Tinjuan Yuridis, Jakarta: PT Gramedia, 1986, P. 9.
} 
the waist made of leather. Then the word budget in England developed means to be a place for letters made of leather, especially those leather bags that are used by the Minister of Finance to store budget documents.

At the time of the Dutch East Indies the government used budgetary words in a formal manner; these words were used both in the Reglement Regering era (RR), as well as in the Indische Staatsregeling (IS) era. During the Japanese occupation period based on the Gunseikan regulation of 2603, the term "budget" was used. Then since the Proclamation on August 17, 1945, the term "Revenue and Expenditure Budget" was used in Article 23 paragraph (1) of the 1945 Constitution, which in the subsequent development also officially added the word "State", so that the term "Income Budget and State Expenditures "abbreviated as APBN. ${ }^{20}$

Regarding the provisions of Article 23 of the 1945 Constitution before amending, Harun Al-Rasjid interpreted state finances in a narrow sense, namely only related to the State Budget. Harun Al-Rasjid also interpreted the provisions of paragraph (5) based on the grammar, history, and purpose of the intended legal procedure. For the latter interpretation, namely the interpretation according to the law (teleologishce interpretatie), Harun Al-Rasjid came to the conclusion that the task of the BPK in examining the government's responsibility regarding state finances was related to the State Budget that had been approved by the DPR, to whom the inspection must be informed. So that it is known whether the government has implemented the budget properly. ${ }^{21}$

In an effort to interpret the definition of state finance as set forth in paragraph (5) of Article 23 of the 1945 Constitution, does the APBN mean merely or does it mean another "plus" state budget?

In this connection, legal expert A. Hamid S. Attamimi explained the two interpretive constructs as follows ${ }^{22}$ : Paragraph (1) stipulates that the APBN must be stipulated by law. Paragraph (5) stipulates that the BPK is held to examine the government's responsibility regarding state finances. Explanation Paragraph (5) states that to examine the government's responsibility on how to use the expenditure money that has been approved by the DPR, a BPK is needed. So even though in Paragraph (5) it is not called the APBN, it is only state finances, but the explanation of the paragraph shows the APBN. Thus, what is meant by state finance is the state budget. Paragraph (1) determines the APBN must be stipulated by law. Paragraph (4) stipulates that state finances must be regulated by law. It is clear that the definition of APBN and state finances needs to be further investigated whether or not the two things are different because if it is the same thing, it certainly does not need to be regulated in Paragraph (1) and Paragraph (4) separately, just in one verse. In addition to Paragraph (1) the Act is formal, while in Paragraph (4) the material Law is in addition to formal. Does this mean that the BPK only checks the state finances as stated in Paragraph (5) and does not examine the state budget because the state finances and the state budget are like two different things. Here is the explanation function Paragraph (5). The explanation of this paragraph mentions the concrete areas of government responsibility in state finance (how to use state expenditure that has been approved by the DPR to be commensurate with the APBN Act). Because Paragraph (5) which mentions the state finances by its explanation is called a concrete field of use of the State

\footnotetext{
${ }^{20}$ Ibid., P. 10.

${ }^{21}$ Arifin P. Soeria Atmaja, Keuangan Publik Dalam Perspektif Hukum: Teori, Praktik, dan Kritik, The University of Indonesia Faculty of Law Publishing Agency, Jakarta, 2005, P. 96.

${ }^{22}$ A. Hamid S. Attamimi in Arifin P. Soeria Atmadja, Ibid, pp. 10-11.
} 
Budget, in the sense of state finance as contained in Paragraph (4) and thus also in Paragraph (5) further conclusions can be drawn that is meant by state finance is including the State Budget. In other words, the definition of state finance includes other "plus" APBNs.

On the other hand, according to Arifin P. Soeria Atmadja, the definition of state finance can be understood in three interpretations, namely, first, the definition of state finance is narrowly interpreted, which only covers finance originating from the state budget. Secondly, state finance in the broadest sense, which includes state finances originating from the state budget, regional budgets, state-owned enterprises, enterprises and in essence all state assets, as a state financial system. Third, if the purpose of interpreting state finances is to know the management system and its accountability, then the definition of state finances is narrow, then to know the system of supervision and audit of accountability, the definition of state finance is in the broadest sense, which includes finance within APBN, APBD, BUMN/D and essentially all state wealth is the object of inspection and supervision. ${ }^{23}$

Article 23 Paragraph (1) of the 1945 Constitution considers the APBN as a form of management of state finances, something that is not properly formulated in a constitution. With this perspective, the APBN must be the basis of budget sovereignty, so that the conceptualization of budget policy is a conceptualization of the sovereignty of all sectors to achieve the goal of the state. In its practical level, the National Budget as a form of popular sovereignty shows an efficient posture in organizing general government, but on the other hand has a fast responsiveness in public services. Thus, the National Budget is based on people's sovereignty in its policies, but is prosperous in its results. ${ }^{24}$

In Article 1 ICW (Indiesche Compabiliteits Wet) is not given a legal limit on the definition of state finance. However, it only explained, "The finances of State of Indonesia Republic are managed and accounted for according to the regulations stipulated in this law. This means that what is meant by state finance in ICW is the state budget. In 1933 Number 320 concerning the Instructie Algemene Rekenkamer (Supreme Audit Agency) stated that it received funds and foundations whose finances must be accountable to the BPK. This means that there is an expansion of financial audits conducted by the BPK, which according to Article 23 Paragraph (5) of the 1945 Constitution states, "to examine the responsibility for state finances a Supreme Audit Agency is held, whose rules are stipulated by law. The results of the examination were notified to the House of Representatives." 25

\section{Conclusion}

Based on the description above shows that the development of BUMN as a corporation that carries out social and business missions faces constitutional juridical problems and faces the challenges of globalization. Factually, at this time legal development cannot be separated from the influence of globalization. Globalization in the economic field has affected various fields of the business sector in the world. Globalization is followed by the globalization of law, which causes substantially various laws and agreements to spread across national borders, which causes the merging of legal principles (especially in the economic sector) from one

\footnotetext{
${ }^{23}$ Arifin P. Soeria Atmaja, Keuangan Publik Dalam Perspektif Hukum: Teori, Praktik, dan Kritik, Rajawali Pers, Jakarta, 2010, P. 4.

${ }^{24}$ Ibid, pp. 109-110.

${ }^{25}$ Ibid, P. 112.
} 
country to another. For Indonesia, the logical consequence of this development is the demand to harmonize the principles of economic law in Indonesia, with the principles of economic law in the international world. Without harmonization, Indonesia can be ostracized in international business activities, because there is no certainty for legal protection for business and investment activities that are commonly carried out globally. ${ }^{26}$

On the other hand, which is in line with globalization, the development of the Indonesian legal system must be based on one of them as the state philosophy (philosofische gronslag). The Pancasila is used as the basis for regulating state governance and the basis for regulating the administration of the state. There are five principles as philosofische grondslag for Indonesia, namely Indonesian nationality, internationalism or humanitarianism, consensus or democracy, cultured social welfare and divinity. ${ }^{27}$

Pancasila, as philosophical ideal values need translation in the form of legislative rules. If seen at the opening of the 1945 Constitution, it can be concluded that UUD which is the constitution of Indonesia, internalized the principles of Pancasila philosophical values. In economic activities, Jimly ${ }^{28}$ said that the 1945 Constitution as the highest source of law or constitution, not only contained provisions in the political field, but also regulated in the economic field according to Jimly, when the fourth amendment to the UUD in 2012, the title Chapter XIV became "Economic National and Social Welfare, with more detailed content than previously contained in Articles 33 and 34.

\section{References}

A. Hamid S. Attamimi dalam Arifin P. Soeria Atmadja, Ibid, pp. 10-11.

Aminuddin Ilmar, Hak Menguasai Negara Dalam Privatisasi BUMN, kencana Prenada Media Grup, Jakarta, 2012, p. 73.

Arifin P. Soeria Atmadja, Mekanisme Pertanggungjawaban Keuangan Negara: Suatu Tinjuan Yuridis, Jakarta: PT Gramedia, 1986, p. 9.

Arifin P. Soeria Atmaja, Keuangan Publik Dalam Perspektif Hukum: Teori, Praktik, dan Kritik, Badan Publisher of the Faculty of Law, University of Indonesia, Jakarta, 2005, p. 96.

Arifin P Soeriatmaja, "Badan Pemeriksa Keuangan Selaku Auditor dari Perspektif BUMN," Business Law Journal, Volume No.26 No.1 of 2007, p. 26.

Bismar Nasution, "Pengaturan Dan Pengawasan Lembaga Jasa Keuangan Menurut UndangUndang Nomor 21 Tahun 2011 Tentang Otoritas Jasa Keuangan”, Paper, Presented in the Socialization of Law Number 21 of 2011 concerning the Financial Services Authority, Integrated Financial Services Industry Supervision, carried out by the Capital Market and Financial Institution Supervisory Agency in collaboration with the Medan Area University, Santika Hotel Medan, 19 June 2012, p. 2.

Bismar Nasution, "Tanggung jawab Direksi dan Komisaris Dalam Pengelolaan Perseroan Terbatas Bank", Paper presented at the Bank Management Day Seminar, held by Bank Indonesia and the Banking Compliance Text Communication Forum. Surabaya, 21

\footnotetext{
${ }^{26}$ Bismar Nasution, "Tanggung jawab Direksi dan Komisaris Dalam Pengelolaan Perseroan Terbatas Bank", Paper presented at the Bank Management Day Seminar, held by Bank Indonesia and the Banking Compliance Text Communication Forum. Surabaya, 21 February 2008. P 1.

${ }^{27}$ Dahlan Thaib, Jazim Hamidi dan Ni'matul Huda, Teori Hukum dan Konstitusi, Jakarta: Rajawali Pers, 1999

${ }^{28}$ Jimly Asshiddiqie, Konstitusi Ekonomi, PT. Kompas Media Nusantara, Jakarta 2010. P. IX.
} 
February 2008. p 1. Dahlan Thaib, Jazim Hamidi and Ni'matul Huda, Teori Hukum dan Konstitusi, Jakarta: Rajawali Pers, 1999, p. 91.

Byan A Camer, Black's Law Dictionary, Thomson West, Massachusetts, p. 200.

Data observation, conducted by Sindonews.com, from https://ekbis.sindonews.com/read/1308869/35/28-bank-terbesar-dunia-beraset-lebihusd1-triliun-11-dari-asia-1527226276

Hendra Setiawan Boen, Bianglala Business Judgment Rule, PT Tata Nusa, Jakarta, 2008, p. 100.

Jimly Asshiddiqie, Pokok-Pokok Hukum Tata Negara Indonesia Pasca Reformasi, print. II, Jakarta: Bhuana Ilmu Populer, 2008, pp. 833-834.

Jimly Asshiddiqie, Konstitusi Ekonomi, PT. Kompas Media Nusantara, Jakarta 2010. P. IX.

Otto Eckstein, Keuangan Negara, terjemahan dari "Public Finance", Jakarta: PT Bina Aksara, 1981, p. 45.

Peter V. Letsou, "Implications of Shareholder Diversification on Corporate Law And

Organization: The Case Of The Business Judgment Rule", 77 Chicago-Kent Law Review (2001), p. 181.

Prasetio, Dilema BUMN Benturan Penerapan Business Judgment Rule (BJR), PT Rayyana Komunikasindo, Jakarta, 2014, pp. 143-144.

Prasetio, Dilemma BUMN Benturan Penerapan Business Judgement Rule (BJR) Dalam Keputusan Bisnis Direksi BUMN, Rayyana Komunikasindo, Jakarta, 2014, p. 79.

Ridwan Khairandy "Konsepsi Kekayaan Negara yang Dipisahkan Dalam Perusahaan Negara" Business Law Journal, Volume No.26 No.1 of 2007, p. 32.

Safri Nugraha, "Privatisasi BUMN, antara Harapan dan Kenyataan" Business Law Journal, Volume No.26 No.1 of 2007, p.16.

Sutan Remy Sjahdeini, Tanggungjawab Pribadi Direksi dan Komisaris, Business Law Journal Volume 14, July 2001.

Sri Redjeki Hartono, Hukum Ekonomi Indonesia, Bayu Media Publishing, Malang, 2007, p.V. Tjip Ismail, "Peranan BUMN dalam Perspektif Pendapatan Negara: Tinjauan Dari Perspektif Pajak"” Business Law Journal, Volume No.26 No.1 of 2007, p. 40.

W. Riawan Tjandra, Hukum Keuangan Negara, Penerbit PT Gramedia Widiasarana Indonesia, Jakarta, 2006, p. 1-3. 